\title{
Conducción y gerencia en la Oficina de Gestión Judicial Poder Judicial de la Provincia de Santa Fe
}

\author{
Leading and management in the Office of Judicial Management \\ Judicial Power of Santa Fe Province \\ Condução e gestão no Gabinete de Gestão Judiciária \\ Poder Judiciário da Província de Santa Fe
}

\author{
Mariana Jimena Drago \\ Universidad Nacional del Litoral, \\ Argentina. \\ E-mail:marianadrago@gigared.com
}

Fecha de recepción: 01/08/2017

Fecha de aceptación: 15/12/2017

Palabras clave

- Gestión pública

- Funciones directivas y gerenciales

- Habilidades directivas

- Tecnologías gerenciales

- Técnicas directivas

Keywords

- Public management

- Managerial functions

- Management skills

- Management technologies

- Management techniques

\section{Resumen}

La conducción y la gerencia en las organizaciones del Estado se desarrollan en un ambiente no sólo gerencial sino también político. Por esta razón, la gestión pública es más compleja que la gestión privada. En el sector público hay diversidad de actores involucrados, los intereses son en ocasiones contradictorios, el dirigente debe lograr el consenso en torno a sus proposiciones, las reglas son rigurosas y los resultados no son fáciles de medir.

En este contexto y bajo la luz de los diferentes expositores en la materia, en el presente trabajo se analizará la situación actual de la Oficina de Gestión Judicial, perteneciente al Poder Judicial de la Provincia de Santa $\mathrm{Fe}$, y se realizará un informe propositivo para el modelo de gestión en que se desarrolla.
Abstract
Leading and management in state organizations are developed in both managerial and political domains. For this reason, public management is more complex than private management. In the public sector, there is a diversity of actors involved, interests are sometimes contradictory, leaders must reach agreements on their proposals, rules are rigorous and results are not easy to measure. 
Palavras-chave

- Gestão pública

- Diretivas e funções de gestão

- Competências de gestão

- Tecnologias de gestão

- Diretivas técnicas
In this context, and in the light of the different experts on the subject, the present work will analyze the current situation of the Office of Judicial Management, which belongs to the Judicial Power of Santa Fe Province, and will conduct a proposal report for its management model.

\section{Resumo}

A condução e a gestão nas organizações do Estado desenvolvem-se em um ambiente não só de gestão, mas também político. Por esta razão, a gestão pública é mais complexa do que a gestão privada. No setor público, há diversidade de atores, envolvidos, os interesses são, às vezes contraditórios, 0 dirigente deve conseguir 0 consenso sobre as suas propostas, as regras são rígidas e os resultados não são fáceis de medir.

Neste contexto e à luz dos diferentes expositores na matéria, no presente trabalho será analisada a situação atual do Gabinete de Gestão Judiciária, pertencente ao Poder Judiciário da Província de Santa $\mathrm{Fe}$, e será realizado um relatório proativo para o modelo de gestão no que ela se desenvolve. 